\title{
Evaluation of Criteria for Uniformity of Roller-Compacted Concrete
}

by Brian H. Green, Billy D. Neeley, Toy S. Poole

U.S. Army Corps of Engineers

Waterways Experiment Station

3909 Halls Ferry Road

Vicksburg, MS 39180-6199

Final report

Approved for public release; distribution is unlimited

\footnotetext{
Prepared for U.S. Army Corps of Engineers

Washington, DC 20314-1000

Under $\quad$ Work Unit 32639
} 